\title{
Participatory Rural Appraisal on Cowpea Production Constraints and Farmers' Management Practices in Burkina Faso
}

\author{
Adelaïde P. Ouedraogo ${ }^{1}$, Agyemang Danquah ${ }^{2}$, Jean-Baptiste Tignegre ${ }^{3}$, Benoit J. Batieno ${ }^{1}$, Herve Bama ${ }^{1}$, \\ Dieudonne Ilboudo ${ }^{1}$, Jeremy T. Ouedraogo ${ }^{4}$, Jonathan N. Ayertey ${ }^{2} \&$ Kwadwo Ofori $^{2}$ \\ ${ }^{1}$ Institut de l'Environnement et de Recherches Agricoles (INERA) \\ ${ }^{2}$ West Africa Centre for Crop Improvement (WACCI) \\ ${ }^{3}$ AVDRC-The World Vegetable Center \\ ${ }^{4}$ African Biosafety Network of Expertise (ABNE) \\ Correspondence: Adelaïde P. Ouedraogo, Institut de 1'Environnement et de Recherches Agricoles (INERA), \\ Genetic and Plant Biotechnology Lab. of INERA (Kamboinsé), Bp 476 Ouagadougou 01, Burkina Faso.
}

Received: August 25, 2020

doi:10.5539/mas.v14n11p9
Accepted: October 7, 2020

Online Published: October 15, 2020

URL: https://doi.org/10.5539/mas.v14n11p9

\begin{abstract}
Success of cowpea cultivation requires a strong understanding of production constraints in order to overcome them. It is thus useful to know whether smallholder cowpea growers use modern or indigenous means to overcome these challenges. We completed a participatory rural appraisal (PRA) study to identify current cowpea production constraints and management practices in Burkina Faso. We interviewed 481 cowpea growers (219 women and $262 \mathrm{men}$ ) and used a mixed-method design of collecting both qualitative and quantitative data. The results showed that water scarcity, damage due to insects, plant diseases, striga, lack of training, and marketing challenges are the main constraints to cowpea production. Among insects reducing cowpea yield, growers identified aphids as a major pest. However, growers often did not know the biology and incidence of insects in their fields. This study also identified local resistant cowpea varieties in various locations.
\end{abstract}

Keywords: cowpea, qualitative and quantitative data, PRA

\section{Introduction}

Rural African communities rely on smallholder farming as a primary source of food (World Bank, 2008). In Sub-Saharan Africa, agricultural production is dominated by smallholder households, which make up around $80 \%$ of farms (FAO-OECD, 2016). In Burkina Faso, nearly 86\% of the population is involved in agriculture, which accounts for $35-40 \%$ of the country's GDP (DGESS, 2018). Thus, agriculture is a key sector that contributes heavily to the country's economic growth, and identification of crop production constraints is an important step in improving productivity. It is also valuable to determine whether smallholder growers use modern or indigenous means to overcome constraints to identify what they could do to increase production.

There are biotic, abiotic, and socioeconomic cowpea production constraints (Tignegre, 2010). Numerous researchers have assessed farmers' ability to overcome crop production constraints (Ayanlade et al., 2016; Mutunga et al., 2017). In cowpea production, biotic stresses include diseases, plant pests, and parasitic phanerogams (Samaila et al., 2019). Major abiotic constraints are soil degradation and rainfall irregularity. Socioeconomic constraints include market issues, access to good land, limited access to input, and lack of agricultural equipment (Tignegre, 2010). One of the major threats to cowpea production is insect pests (Oyewale \& Bamaiyi, 2013; Tignegre, 2010). Among these, cowpea aphid (Aphis craccivora Koch) is economically important. Without any control measures, aphid infestations can cause about 50\% yield losses in cowpea crops (Obopile, 2006). Aphids are also major vectors of plant viruses (Blackman \& Eastop, 2000).

This participatory rural appraisal (PRA) not only identified current cowpea production constraints but also ascertained farmers' solutions and requirements for better yields. Additionally, the study identified aphids as an important factor in reducing cowpea yields and investigated farmers' insect awareness and management. Finally, this PRA identified local resistant cowpea varieties in various locations. This study aimed to do the following:

- Identify cowpea production constraints with a focus on aphids. 
- Identify management practices adopted by cowpea growers in managing constraints.

The paper is divided into five sections. After the introduction, the materials and methodology used to collect the data are displayed in section two. The results are presented in section three and discussed in section four. Section five includes the conclusion and perspectives.

\section{Materials and Methods}

\subsection{Study Areas}

We conducted participatory rural appraisals (PRAs) of farmers in nine districts in three climatic zones (see Figure 1): the district of Soum, which belongs to the Sahelian zone (300 to $600 \mathrm{~mm}$ of rainfall annually); the districts of Zondoma, Bam, Sanmatenga, and N'Gourma, which belong to the Sudano-Sahelian zone (600 to 900 $\mathrm{mm}$ of rainfall annually); and the districts of Comoé, Houet, and Kenedougou, which belong to the Sudanian zone (900 to $1200 \mathrm{~mm}$ of rainfall annually).

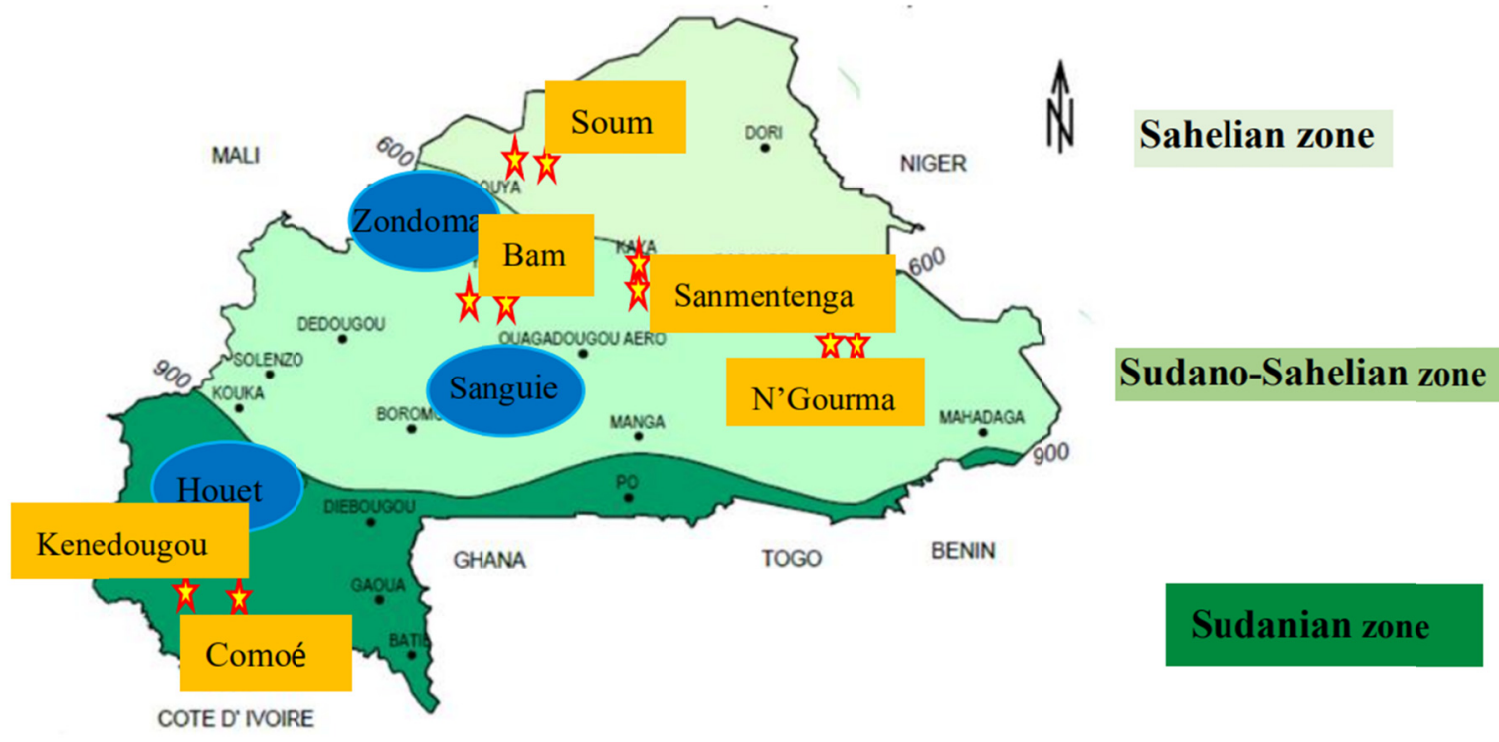

Figure 1. Climatic Zones of Burkina Faso

Source: Burkina Faso Meteorological General Directorate.

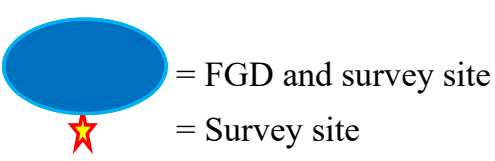

\subsection{Sampling, Data Collection, and Analysis}

We conducted this study between October and December 2017, focusing on cowpea growers. We used a mixed-methods design of collecting both qualitative and quantitative data. The sampling procedure was purposive for the focus group discussion (FGD) sites and random for the survey sites. We selected an unequal number of districts per climatic zone by including a higher number of districts from larger climatic zones. This was a proximity survey. The PRA was scheduled to include all three of Burkina Faso's climatic zones. The districts of particular interest to the FGDs were Zondoma, Houet, and Sanguie; in these sites, 83 cowpea producers attended the discussions. Among them, 38 were female and 45 were male. After the FGDs, we questioned farmers individually. We also administered the same questionnaire to 398 cowpea growers from six districts (Comoé, Bam, Sanmatenga, Kenedougou, N'Gourma, and Soum). In this group, 181 participants were female and 217 were male. In total, we interviewed 481 cowpea growers ( 219 women and 262 men), used the data collected to build charts and pie charts, and utilized the statistical package $\mathrm{R}$ version 3.5 .1 to compute the data.

\section{Results}

\subsection{General Summary of the Data}

Cowpea growers ranged from 14 to 80 years of age (see Figure 2). Among the interviewed cowpea growers, 54\% were men and $46 \%$ were women (see Figure 3). 


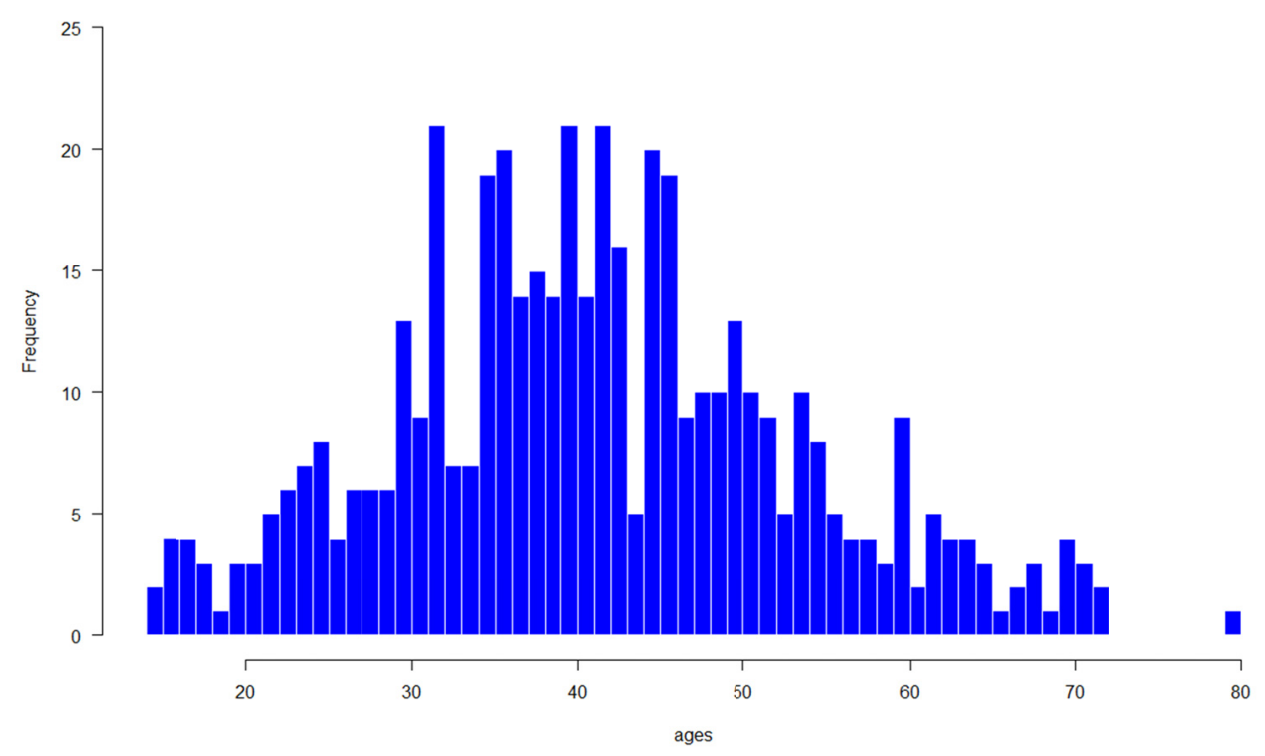

Figure 2. Age Distribution of Cowpea Growers

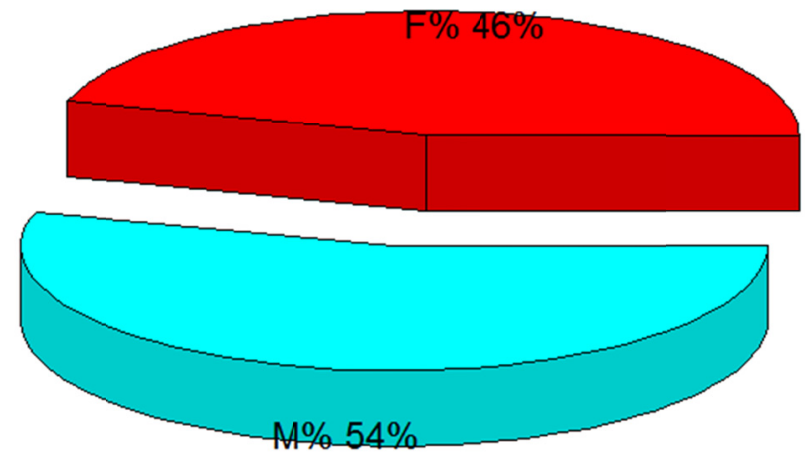

Figure 3. Gender of Cowpea Growers

Note. $\mathrm{M} \%=$ percentage of males; $\mathrm{F} \%=$ percentage of females.

\subsection{Cowpea Production Constraints}

In each of the three FGD areas, we ascertained the following cowpea production constraints: drought, production means (plowing and harvest equipment) shortages, insect pests in the field and storage, damping off of seedlings, and lack of confidence in pesticides and fertilizers. These constraints also included cowpea marketing challenges and the problem of reliability of certified seeds sold in marketplaces. Other constraints were the Striga parasitic weed, high cost of inputs (fertilizer, pesticides etc), and weakness of farmers' capacity building.

According to cowpea growers, water is a limiting factor to crop production in general, and water scarcity is a challenge in all three climatic zones. Growers believe that the irregular rainfall affects cowpea production and aggravates the effects of pests like aphids.

Insect pests are also a major constraint to cowpea production. Almost all cowpea growers questioned were aware of aphids and their harmfulness to cowpeas (see Figure 4). In fact, 99\% of them were able to identify aphids as a cowpea pest. The few cowpea growers who were not able to identify aphids as cowpea pests were located in two districts: Sanmatenga and Houet (see Figure 5). At the vegetative stage, aphids first attack in the field, especially if drought occurs. Overall, $95 \%$ of cowpea growers believe that aphids are harmful to local varieties, and $85 \%$ think that aphids are also harmful to improved varieties. According to farmers, aphids drastically reduce cowpea production. They also noticed resurgences of aphids after spraying with pesticides. Growers believe that aphids are not the only species capable of causing damage to cowpeas; millipedes also eat seeds, whether germinated or not. They believe that at the seedling stage, ants also climb on the plants and deposit eggs. According to the growers, worms also attack cowpeas during the development stages. Worms, butterflies, and moths also gnaw 
cowpea pods and seeds. About $60 \%$ of cowpea growers believe that aphids infest only cowpeas, whereas $39.4 \%$ of them think there are other host plant species infested by aphids (see Figure 4).

Adequate field equipment, according to cowpea growers, is a key factor that increases crop productivity. Lack of this equipment prevents them from following the planting calendar. Cowpea growers also think that certified seeds need more attention. They believe that mechanization will help them follow the cultivation practices required by certified seeds.

Additionally, growers cited lack of confidence in chemical fertilizers and pesticides as well as problems with the reliability of certified seeds. When asked to compare certified seeds bought in different stores to their own seeds, cowpea farmers said that there were differences in quality, depending on the store. They said that they purchased certified seeds either from stores or directly from seed companies, and they believe that seeds from companies perform better than their own seeds (taken from the field); however, seeds purchased in some stores are similar to those taken from the field.

Selling their cowpea crop is also a challenge for farmers. In addition, growers cited Striga, access to input, and the weakness of farmers' capacity building as constraints to cowpea production.

\subsection{Management Practices Adopted by Cowpea Growers}

To solve the problem of water scarcity, producers have devised various solutions. Some use surface water by way of rivers and wheels during droughts. Other solutions include motorized water pumps and gravity irrigation for fields near water points. It is possible to construct small water storage points for fields that are far from water points ("Bassins de collecte d'eau de ruissellement"). However, the high cost of this infrastructure and the rapid evaporation of water from the basins do not encourage producers to adopt this technology.

Only $19.2 \%$ of farmers know traditional ways to control aphids (see Figure 4). In contrast, more than $90 \%$ know of modern cowpea aphid management strategies, such as using chemical pesticides, but their frequency of use could not be determined. Among farmers who are aware of chemical means of aphid control, $77.6 \%$ believe they know the recommended doses (see Figure 7). Only $4.9 \%$ of farmers know local aphid-resistant cowpea varieties (Figure 4). The farmers who claimed they knew local aphid-resistant varieties were located in six districts out of the nine covered by the study (see Figure 6).

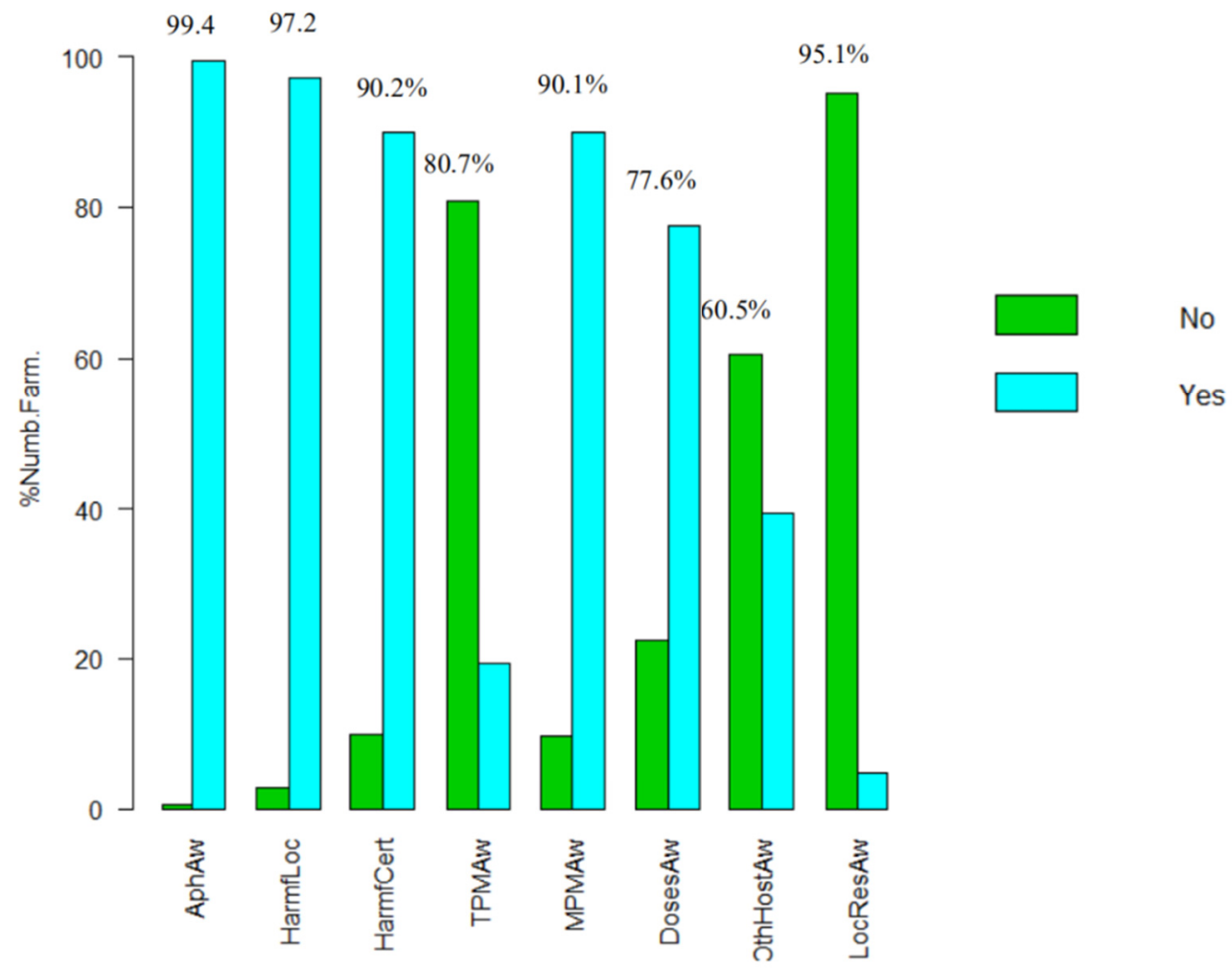

Figure 4. Percentage of Cowpea Growers' Overall Awareness of Aphids and Their Control

Note. AphAw $=$ Aphids awareness; HarmfLoc $=$ Harmfulness on local varieties; HarmfCert $=$ Harmfulness on certified varieties; TPMAw $=$ Traditional pest management awareness; MPMAw $=$ Modern pest management 
awareness; DosesAw = Doses awareness; OthHostAw = Other host plants awareness; LocResAw = Local resistant varieties awareness.

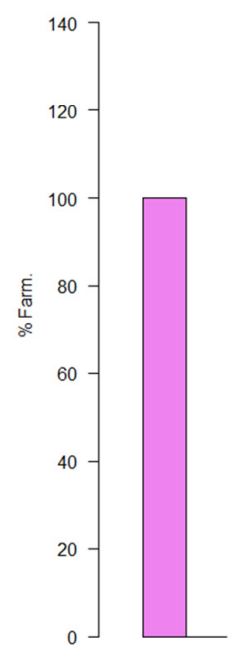

Bam

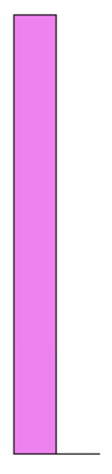

Com

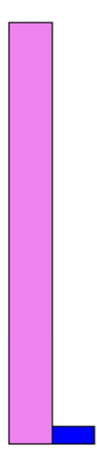

Hou

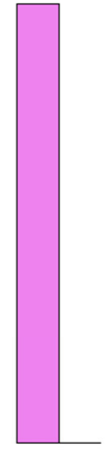

Ken

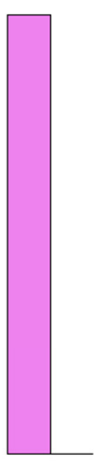

Gour
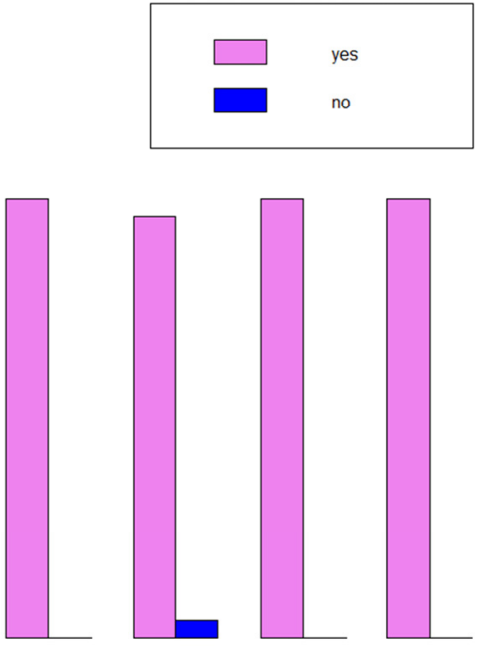

Soum Zond

Figure 5. Percentage of Cowpea Growers' Awareness of Aphids by District

Note . Bam = District of Bam; Com = District of Comoé; Hou = District of Houet; Ken = District of Kenedougou; Gour = District of Fada N'Gourma; Sang = District of Sanguie; Sanm = District of Sanmatenga; Soum = District of Soum; Zond = District of Zondoma.

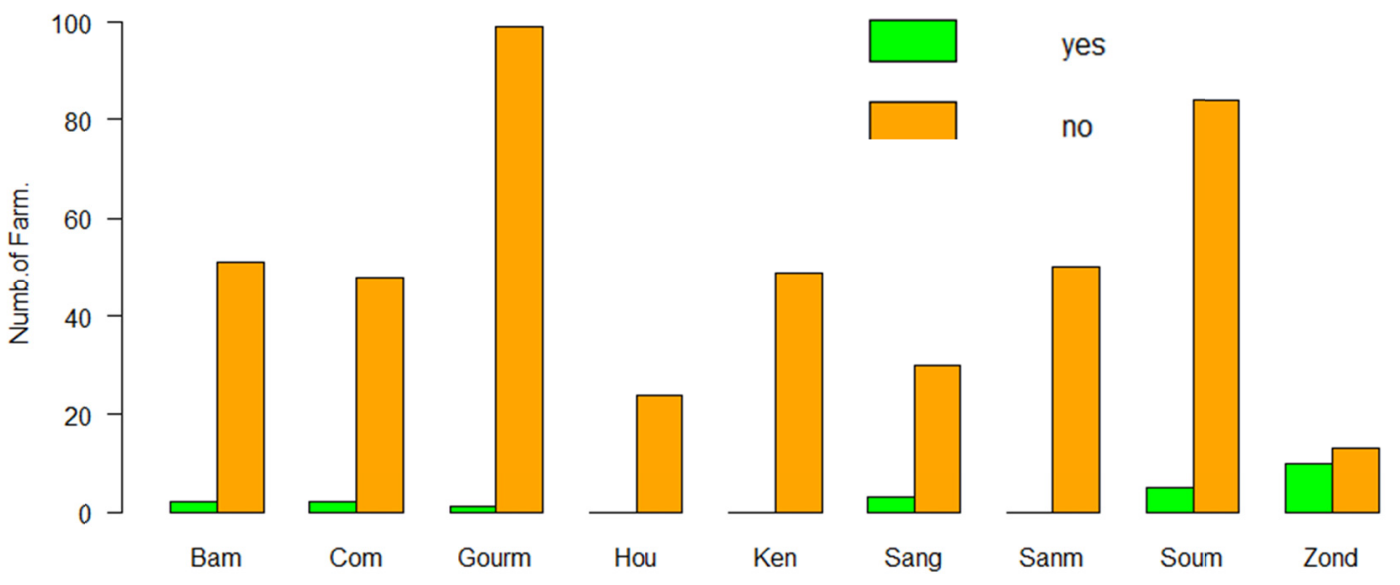

Figure 6. Cowpea Growers' Awareness of Local Resistant Varieties by District

Note. Numb. of Farm. = Number of farmers; Bam $=$ District of Bam; Com $=$ District of Comoé; Gourm $=$ District of Fada N'Gourma; Hou = District of Houet; Ken = District of Kenedougou; Sang = District of Sanguie; Sanm $=$ District of Sanmatenga; Soum $=$ District of Soum; Zond = District of Zondoma. 


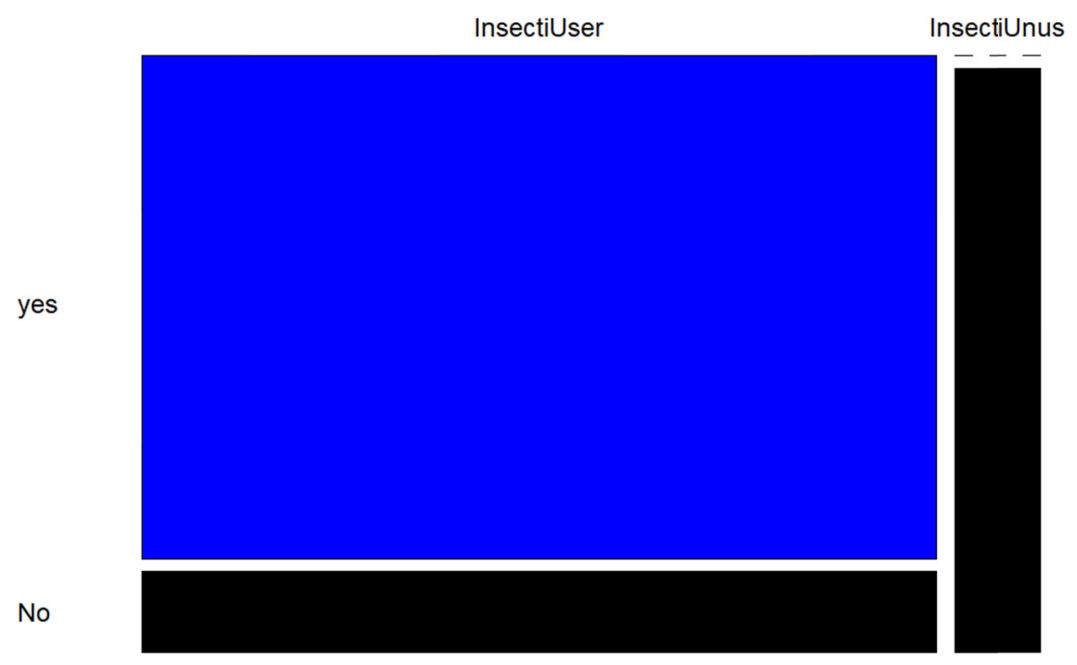

Figure 7. Percentage of Cowpea Growers' Insecticide Dose Awareness

Note. InsectiUser $=$ Insecticides users; InsectiUnus = Insecticides nonusers.

\section{Discussion}

During the FGDs, cowpea growers stated that they believe the rainy season is becoming shorter and the rains irregular. This shows the impact of climate variation on crop production and the need to make farmers aware of improved varieties adapted to this variation. Climate change is of universal concern, having already decreased crop yields in several regions of the world. Without adaptation, total production of maize in Africa would decrease by $12-40 \%$ per year (Ramirez-Villegas \& Thronton, 2015). Therefore, smallholder farmers are greatly vulnerable to these changes (Komba \& Muchapondwa, 2012; Morton, 2007). For Sahelian countries, climate change means that some crops that are adapted to a historic climatic zone can no longer be grown (Ramirez-Villegas \& Thronton, 2015). Adaptations to increase resilience to climate change include better water management (Wolfe et al., 2018) and selective breeding. For example, a heat tolerant accession of tepary bean (Phaseolus acutifolius) was used to produce heat tolerant lines (Beebe et al., 2011). According to Jarvis et al. (2012), shifting to more adapted crop varieties could be enough sometimes to mitigate the effects of climate variation in crop production. In Burkina Faso's case, varieties historically adapted to the Sahelian zone could be tested in the Sudano-Sahelian zone, and those historically adapted to the Sudano-Sahelian zone could be tested in the Sudanian zone to assess their performance. Using the same logic, varieties historically adapted to the most arid zones in the country, or elsewhere in the world, could be tested in the Sahelian zone. To tackle water scarcity in the context of crop production, more effort should be put into using underground water because it is well known to be more resilient to the effects of climate change than surface water (UNESCO, 2012). Even though climate variation is affecting crop production by creating unprecedented challenges for farmers, new opportunities are possible (Ramirez-Villegas \& Thronton, 2015; Wolfe et al., 2018).

According to farmers, diseases (seedlings damping off) and pest control are also key factors to cowpea production. They specifically emphasized aphids, stating that they prevent plants from growing. Aphids delay the development of the plant, causing leaves to curl up and draw all the strength out of the seedlings. Cowpea farmers also observed that aphids are seen during the seedling, flowering, and pod stages, in accordance with the research findings. Yadav et al. (2015) found that aphids, whiteflies, and leafhoppers were the first to invade cowpeas at the early growth stage (one week after sowing). Aphids are also seen on cowpeas throughout the crop period (Augustine, 2011; Srikanth \& Lakkundi, 1990; Yadav et al., 2015). Farmers in our study noticed that attacked plants sometimes have only one pod, which frequently has no grain. Even when grains are found inside, they are of poor quality and remain hard when cooked. These observations regarding aphid-infested cowpeas have been confirmed by the research. Aphis craccivora is particularly known to decrease seed quality (Laamari et al., 2008; Obopile, 2006).

Farmers are aware of aphids as a major cowpea pest. However, it should be highlighted that although producers are aware of the role of insects in decreasing yields in cowpeas, some lack knowledge of the biology and the role insects play in their fields. For example, the idea that butterflies (insects of the Lepidoptera order) gnaw on cowpea leaves is evidence of farmers' confusion of the stages (egg, larva, and pupa) that insects need to go 
through to reach adulthood. Some insects, like butterflies, have complete metamorphosis: The egg is different from the larva, the larva from the pupa, and the pupa from the adult. Thus, the same insect species can show several evolutionary stages in a given field, leading to farmers' confusion.

The presence of ants on cowpea plants, noticed by farmers in our study, has been confirmed by researchers. In fact, even though ants do not attack cowpeas, they may be found on several plant species among which, cowpea. Aphids and ants develop a mutualistic relationship; ants offer protection from predators and disease vectors, and, in turn, aphids produce a sugar-rich substance known as honeydew that provides ants with nutrients (Begon et al., 2011; Detrain et al., 2010). Depending on the ecological characteristics, interactions between ants and aphids may split from mutualistic to antagonistic (Stadler \& Dixon, 2005; Billick et al., 2007). It is useful for cowpea growers to have at least general knowledge of diseases and pests that occur in their fields. Knowing these diseases, their causes, and the periods at which they occur will help farmers better monitor for efficient crop management. The use of any integrated pest management (IPM) method requires knowledge of the targeted insect's life history, ecology, and population dynamics, as well as knowledge about the host (Arif \& Gogi, 2017; Gómez, 2004).

Cowpea growers in our study think using pesticides can control aphids even if there are some cases of resurgence. They stated that neem (Azadiratcha indica) leaves can be used to treat insects in small areas, but treatment must be started early. The treatment mixture is made from neem leaves and water. Soap can be added to the mixture to improve its adherence to plant leaves. Previous studies have confirmed that neem products (leaves, seeds, and oil) have pest control properties (Baidoo, 2012; Djinadou et al., 2009), and about 400 insect species are susceptible to neem products (Schmutterer, 1990). These products act either as antifeedant, repellent, or hormonal and growth inhibitors (Mikami \& Ventura, 2008). Additionally, farmers in our study often used garlic against insects, but only in small areas. One solution farmers proposed against millipedes is to soak seeds with gasoline before sowing. Farmers believe this prevents the millipedes from perforating the seeds. However, they noticed that when plants were treated with a lot of pesticides, leaves fell off just after harvest and yet, fodder is useful for feeding livestock. Farmers also said they hesitate to feed their cattle with cowpea haulm when plants have been over sprayed with pesticides for fear of poisoning them.

To tackle issues with the means of production, farmers need a supply of agricultural equipment. There is a net crop increase when the land is plowed on time, and according to the growers, inadequate agricultural equipment compromises crop production. Research has identified lack of equipment as one of the most important obstacles in the adoption of sustainable intensification strategies (Riar et al., 2013; Theriault et al., 2017).

Opinions differ as to the best way to acquire equipment. Given the high cost of these machines, some argue for producers to join associations that jointly purchase the equipment. However, this raises other issues. Managing and maintaining equipment requires effort from each member of the association and regular consultations between members, sometimes during the rainy season, a time period when farmers prefer to work in their fields rather than attend meetings. Therefore, some farmers prefer individual equipment acquisition. In turn, these buyers offer to increase plowing capacity for the benefit of all the producers. Some smallholder producers also plead for the acquisition of animal traction plows for their crops.

Previous studies have discussed farmers' problems with input reliability, especially on the subject of pesticides. Some pesticides sold in the marketplace are unlabeled or are stored in inadequate conditions (Tankoano, 2008). Additionally, pesticides containing banned persistent organic pollutants are marketed fraudulently (Ouédraogo \& Toé, 2014). Although regulatory structures exist, weak legal enforcement, inadequate quality control, stakeholders' lack of technical knowledge, and lack of organization for pesticide dealers are barriers to better pesticide control (Ouédraogo \& Toé, 2014). Cowpea grains and seed producers have cited unreliability of certified seeds sold in some markets. Seed producers lament the mistrust of cowpea growers who have faced poor quality seeds or who have heard about the poor quality of certified seeds and do not want to buy them anymore.

Farmers also raised issues about marketing problems, particularly access to local markets and volatility of cowpea prices. In their 2013 study that investigated market access issues, Riar et al. showed that profitability, dictated by the market price, is an important driving force for farmers to include a crop in their farming system. Farmers think that developing other lucrative farming activities, such as livestock or poultry farming, will improve their productivity. They believe these activities will help them buy production input and make their farm more resilient. 
Local sources of aphid resistance are rare. Their locations have been recorded, and a prospection would help to collect these ecotypes as additional sources of aphid resistance. The scattered distribution of these locations throughout the country suggests a great genetic variability between ecotypes.

\section{Conclusion}

This study showed the main constraints to cowpea production are currently water scarcity, damage by insect pests, the damping off of seedlings, lack of training, marketing challenges, Striga, and access to quality input. Water resources exist but initiatives developed for the use of surface water have shown their limits, especially in areas far from water points. The study also demonstrated the need to regulate the input market and reduce pesticide use by breeding crops for insect resistance. The results established that cowpea growers are aware of aphids as pests. However, they are often unfamiliar with the biology of insects occurring in their fields. Aphid-resistant cowpea varieties have been recorded in various locations, and a prospection would help to collect these ecotypes as additional sources of resistance to aphids. It would also be useful to investigate gender-based cowpea production constraints, gender-based farmers' solutions, and expectations.

\section{Acknowledgment}

We wish to thank DAAD and ECONET for founding the PhD research scholarship for the first author. We also thank WACCI-ACE and INERA for their technical support.

\section{References}

Arif, M. J., \& Gogi, M. D. (2017). Principles of Insect Pests Management. In Sustainable Insect Pest Management. University of Agriculture, Faisalabad, Pakistan.

Augustine, S. N. (2011). Arthropod assemblage dynamics on cowpea (Vigna unguiculata L. Walp.) in a subtropical agro-ecosystem, south Africa. African J. Agric. Res., 6(4), 1009-1015.

Ayanlade, A., Radeny, M., \& Morton, J. F. (2016). Comparing smallholder farmers' perception of climate change with meteorological data: A case study from southwestern Nigeria. Weather and Climate Extremes, 15(September 2016), 24-33. https://doi.org/10.1016/j.wace.2016.12.001

Baidoo, P. (2012). Effects of Neem (Azadirachta indica A. Juss) Products on Aphis craccivora and its Predator Harmonia axyridis on Cowpea. American Journal of Experimental Agriculture, 2(2), 198-206. https://doi.org/10.9734/ajea/2012/928

Beebe, S. Ramirez-Villegas, J. Jarvis, A. Rao, I. M. Mosquera, G. Bueno, J. M., \& Blair, M. W. (2011). Genetic Improvement of Common Beans and the Challenges of Climate Change. In Crop Adaptation to Climate Change (Wiley-Blac, pp. 356-369). https://doi.org/10.1002/9780470960929.ch25

Begon, M., Harper, J. L., \& Colin, R. T. (2011). Ecology: From Individuals to Ecosystems. (4th ed. Ma). MA [u.a.: Blackwell Publ.].

Billick, I. Hammer, S. Reithel, J. S., \& Abbot, P. (2007). Ant-aphid interactions: Are ants friends, enemies, or both? Annals of the Entomological Society of America, 100(6), 887-892. https://doi.org/10.1603/0013-8746(2007)100[887:AIAAFE]2.0.CO;2

Blackman, R. L., \& Eastop, V. F. (2000). Aphids on the world' s crops: An identification and information guide.2nd Edition. John Wiley \& Sons. London, UK.

Detrain, C. Verheggen, J. F. Diez, L. W. B., \& H. E. (2010). Aphid-ant Mutualism: How Honeydew Sugars Influence the Behaviour of Ant Scouts. In Physiological Entomology (pp. 168-174). Wiley-Blackwell. https://doi.org/10.1111/j.1365-3032.2010.00730.x

DGESS. (2018). Avril 2018 Direction générale des études et des statistiques sectorielles 03 BP 7009 Ouagadougou 03. 386.

Djinadou, K. A., Adégbola, P. Y., Adegbidi, A. A., Coulibaly, O. N., \& Tossou, C. R. V. (2009). Genre et impact des extraits aqueux de neem sur le revenu et 1 ' allocation des dépenses des producteurs de niébé au sud-ouest du Bénin.Résumé Gender and impact of neem's aqueous extracts on cowpea farmers ' revenues and expenses in the south west of Be. Bulletin de La Recherche Agronomique Du Bénin, pp. 19-26.

Food and Agriculture Organization. (FAO), \& Organization for Economic Co-Operation and Development (OECD). (2016). OECD (Organisation for Economic Co-operation and Development)-FAO Agricultural Outlook 2016-2025. OECD Publishing: Paris, France.

Gómez, C. (2004). COWPEA Post-harvest Operations (F. (Technical) AGST/FAO: Danilo Mejía, Ed.). Rome, 
Italy: Food and Agriculture Organization of the United Nations (FAO).

Jarvis, A. Ramirez-Villegas, J. Herrera, C. B. V., \& Navarro-Racines, C. (2012). Is Cassava the Answer to African Climate Change Adaptation? Tropical Plant Biology, 5, 9-29. https://doi.org/10.1007/s12042-012-9096-7

Komba, C., \& Muchapondwa, E. (2012). Adaptation to Climate Change by Smallholder Farmers in Tanzania Adaptation to Climate Change by Smallholder Farmers in Tanzania. Econ. Res. Southern Afr.(ERSA) Working, (July). Retrieved http://www.econrsa.org/system/files/publications/working_papers/wp299.pdf

Laamari, M. Khelfa, L., \& Coeur D'acier, A. (2008). Resistance source to cowpea aphid (Aphis craccivora Koch) in broad bean (Vicia faba L.) Algerian landrace collection. African Journal of Biotechnology, 7, 2486-2490.

Mikami, A. Y., \& Ventura, M. U. (2008). Repellent, antifeedant and insecticidal effects of neem oil on Microtheca punctigera. Brazilian Archives of Biology and Technology, 51(6), 1121-1126. https://doi.org/10.1590/S1516-89132008000600006

Morton, J. F. (2007). The impact of climate change on smallholder and subsistence agriculture. Proc. Natl. Acad. Sci. U.S.A., 104, 19680-19685. https://doi.org/10.1073/pnas.0701855104

Mutunga, E. J. N. C., \& K., M. P. (2017). Smallholder Farmers Perceptions and Adaptations to Climate Change and Variability in Kitui County, Kenya. Journal of Earth Science \& Climatic Change, 08(03), 389. https://doi.org/10.4172/2157-7617.1000389

Obopile, M. (2006). Economic threshold and injury levels for control of cowpea aphid, Aphis crassivora Linnaeus (Homoptera : Aphididae), on cowpea. African Plant Protection, 12(June), 111-115.

Ouédraogo, M., \& Toé, A. M. (2014). Pesticides in Burkina Faso: Overview of the Situation in a Sahelian African Country. (October 2011). https://doi.org/10.5772/16507

Oyewale, R. O., \& Bamaiyi, L. J. (2013). Management of cowpea insect pests. Sch. Acad. J. Biosci, 1(5), 217-226.

Ramirez-Villegas, J., \& Thronton, P. K. (2015). Climate change impacts on African crop production. CCAFS Working Paper, 119(119), 1-25.

Riar, D. S. Norsworthy, J. K. Steckel, L. E. Stephenson, IV. D. O. Eubank, T. W. Bond, J., \& Scott, R. C. (2013). Adoption of Best Management Practices for Herbicide-Resistant Weeds in Midsouthern United States Cotton, Rice, and Soybean. Weed Technology, 27(4), 788-797. https://doi.org/10.1614/wt-d-13-00087.1

Samaila, A. E., Degri, M. M., \& Mshelia, J. S. (2019). Assessment of Field Insect Pests Damage on Cowpea in Gombe State, Nigeria. Department of Agronomy, Federal University of Kashere, PMB 0182 Gombe State, $4(1), 10-23$.

Schmutterer, H. (1990). Properties and potential of natural pesticides from the neem tree, Azadirachta indica. Annu. Rev. Entomol., 35, 271-297. https://doi.org/10.1146/annurev.en.35.010190.001415

Srikanth, J., \& Lakkundi, N. H. (1990). Seasonal population fluctuations of cowpea aphid Aphis craccivora Koch and its predatory coccinellids. Insect Sci. Applic., 11(1), 21-25. https://doi.org/10.1017/S1742758400019792

Stadler, B., \& Dixon, A. F. G. (2005). Ecology and evolution of aphid-ant interactions. Annual Review of Ecology, Evolution, and Systematics, 36(December 2005), 345-372. https://doi.org/10.1146/annurev.ecolsys.36.091704.175531

Tankoano, A. (2008). Etude du risque toxicologique lié à l'utilisation des pesticides par les producteurs de coton dans la zone cotonnière de l'Est du Burkina Faso. Université de Ouagadougou.

Theriault, V., Smale, M., \& Aider, H. (2017). How Does Gender Affect Sustainable Intensification of Cereal Production in the West African Sahel? World Development, 92, 177-191. https://doi.org/10.1016/j.worlddev.2016.12.003

Tignegre, J. B. (2010). Genetic study of cowpea (vigna unguiculata (1.)Walp.) Resistance to striga gesnerioides (willd.) Vatke in Burkina Faso. MSc Agric., University of Ouagadougou, Burkina Faso A Thesis Submitted in Partial Fulfill, (February), 1-170.

UNESCO (United Nations Educational, S. and C. O.). (2012). Groundwater and Global Change: Trends, Opportunities and Challenges, United Nations Educational, Scientific and Cultural Organization 7, Place 
de Fontenoy, 75352 Paris 07 SP, France. 74-75.

Wolfe, D. W., DeGaetano, A. T., Peck, G. M., Carey, M., Ziska, L. H., Lea-Cox, J., ... Hollinger, D. Y. (2018). Unique challenges and opportunities for northeastern US crop production in a changing climate. Climatic Change, 146(1-2), 231-245. https://doi.org/10.1007/s10584-017-2109-7

WorldBank. (2008). World development report, 2008: agriculture for development. Choice Reviews Online, 45(09), 45-4765. https://doi.org/10.5860/choice.45-4765

Yadav, K. S. Pandya, H.V. Patel, S.M. Patel, S.D., \& Saiyad, M. M. (2015). Population dynamics of major insect pests of cowpea [Vigna ungiculata (L.) Walp.]. International Journal of Plant Protection, 8(1), 112-117. https://doi.org/10.15740/has/ijpp/8.1/112-117

\section{Copyrights}

Copyright for this article is retained by the author(s), with first publication rights granted to the journal.

This is an open-access article distributed under the terms and conditions of the Creative Commons Attribution license (http://creativecommons.org/licenses/by/4.0/). 